\title{
The Effect of International Trade on Employment in Turkey
}

\author{
Seren SAVACI (https://orcid.org/0000-0001-7335-6591), Department of Economics, Dokuz Eylül University, \\ Turkey; e-mail: seren.savaci@ogr.deu.edu.tr
}

Ayşe Dilek SEYMEN (https://orcid.org/0000-0001-5535-594X), Department of Economics, Dokuz Eylül

University, Turkey; e-mail: dilek.seymen@deu.edu.tr

\section{Türkiye’de Uluslararası Ticaretin İstihdam Üzerindeki Etkisi}

\begin{abstract}
The final goods export and import analyses for employment explains the relationship between international trade and employment in a limited way; because a significant part of international trade occurs within international production chains. The international trade structure is based on international production chains, so the effects of international trade on employment are complicated. In addition to the effect on employment of exports and imports; the import content of exports, the export content of imports and the intermediates within imports from a third country have to be considered. The aim of this paper is to reveal the effect of international trade on employment in Turkey through five components, using the World Input Output Table (WIOT) for 2014. The methods proposed in Stehrer et al. (2012) and Xiang (2013) were used to decompose the employment effect of the international trade of Turkey by trading partner and sector. The analysis shows that in 2014, exports led to a demand for about three million jobs in Turkey. International trade in textiles had the highest employment demand, both in Turkey and abroad at the same time. With regard to the analysis by country; international trade with China, India and Indonesia created more employment in those countries than in Turkey.

Keywords : International Production, Employment, WIOD.

JEL Classification Codes : $\quad$ F16, F66.

\section{$\ddot{\mathbf{O} z}$}

Uluslararası ticaret ile istihdam arasındaki ilişkinin açıklanmasında nihai mal ihracat ve ithalatının analizi sınırlı sonuçlar vermektedir; çünkü uluslararası ticaretin önemli bir kısmı uluslararası üretim zincirlerinin bir parçası olarak gerçekleşmektedir. Uluslararası üretim zincirlerine dayanan uluslararası ticaret yapısı, uluslararası ticaretin istihdama olan etkilerini daha karmaşı hale getirmektedir. İhracatın ve ithalatın istihdam etkisine ek olarak; ihracatın ithalat içeriği, ithalatın ihracat içeriği ve üçüncü ülkeden ithal edilen ara malların istihdam etkileri dikkate alınmalıdır. Bu çalışmanın amacı, Türkiye'de uluslararası ticaretin istihdam üzerindeki etkisini 2014 yılı için Dünya Girdi Çıktı Tablosu'nu (WIOT) kullanarak ülkeler ve sektörler düzeyinde yukarıda bahsedilen beş bileşenle açıklamaktır. Çalışma, 2014 yılında ihracatın Türkiye'de yaklaşık 3 milyonluk istihdam talebine yol açtığını göstermektedir. Tekstilde uluslararası ticaret, Türkiye ve yurtdışındaki en yüksek istihdam talebini yaratmaktadır. Ülke analizi ile ilgili olarak; Çin, Hindistan ve Endonezya ile yapılan uluslararası ticaret, bu ülkelerde Türkiye'den daha fazla istihdam yaratmaktadır.
\end{abstract}

Anahtar Sözcükler : Uluslararası Üretim, İstihdam, WIOD. 


\section{Introduction}

The effect of international trade on employment is restricted by the creative and destructive effects of exports and imports, given the final goods trade. The effects of international trade on employment due to comparative advantage depends on the export and import of final goods; however, final commodity trade cannot account for all international trade today. An important part of international trade takes place in the international production chains. A fragmented production process causes the intermediate goods share of international trade to rise; in this way the intermediate goods trade effect on employment also increases. The international trade structure, which is based on international production chains, complicates the effects of international trade on employment. Besides the employment effect of (1) exports and the employment effect of (2) imports, the employment effect of (3) the import content of exports, (4) the export content of imports and (5) the intermediates contained in imports from a third country arise from international production. These effects are discussed in more detail below:

(1) The employment effect of exports: Exports increase output as a component of the ultimate domestic demand, and increased output leads to an increase in the demand for labour force.

(2) The employment effect of imports: Increased import demand means increased production in a foreign country; thus, the main employment effect of imports is increased foreign labour demand. Imported goods are also used as intermediate goods in domestic production, so that imported intermediate goods increase domestic labour demand indirectly, as an input for domestic production.

(3) The employment effect of the import content of exports: Exports from one country may require importing intermediate goods from other countries. For example; a country that exports cheese may need to import milk from another country. The imported milk for cheese export is the import content of the export and it is expected to have a positive effect on employment in that country as it is then becoming an export of the country that imported it.

(4) The employment effect of the export content of imports: A country's imports may include intermediate goods that it has exported. A country that imports cheese from another country may have exported milk to that country. In this case, the import demand is expected to have a positive effect on domestic employment as it will indirectly increase exports.

(5) The employment effect of imports from a third country: The foreign trade between two countries affects the exports and employment in a third country. If a country that exports cheese is importing milk from another country to create a product to export, this is expected to have an employment enhancing effect on the milk exporting country.

These five components illustrate: the employment effect of exports and imports result from the final goods trade; the employment effect of the import content of exports, the export 
content of imports, and imports from a third country are the results of international trade within international production since the components are intermediate goods trade. In addition, the employment effect of exports and the export content of imports, create demand for domestic employment, while the employment effect of imports, the import content of exports and imports from the third country create demand for foreign employment (Jiang \& Milberg, 2013: 3).

In order to determine the employment effects arising from the intermediate goods trade, intermediate goods trade data should be available between countries and at the sectoral level. The WIOD (World Input-Output Database), published in 2016, presents a dataset of input-output tables covering 56 sectors, classified within ISIC Rev. 4 for 43 countries and for 'the rest of the world', including 28 European Union countries and 15 other countries. WIOD is a database supported by the European Union 7th Framework Program to analyse the impacts of globalisation on trade structures, environmental issues and socioeconomic development (Timmer et al., 2015). Since the latest world input-output table available is for 2014, the analysis uses the data set from 2014.

The aim of this study is to reveal the employment effects of international trade in Turkey. Using the latest world input-output table (WIOT) for 2014, the employment effect of Turkey's international trade was analysed at country level, disaggregated by the five components above, and sectoral assessments were made with selected countries.

The main shortcomings of WIOD and the methodology used in this article are twofold. First of all, it is not possible to fully analyse the employment effect of imports from WIOT data. Imports are only considered as a determinant of foreign labour demand and so the indirect effects of import on domestic employment could not be included in the analyses. Second, it is not possible to decompose the employment effect of exports by country and by sector at the same time.

The plan of the paper is as follows: The second section includes a literature review on the employment effect of international trade in Turkey using input-output tables and research using WIOT. In the third section, the method and findings of the study are explained. The decomposition of the five effects was made using Jiang's (2013) method. Jiang (2013) carried out an analysis of 39 countries and 33 sectors for 2009 using WIOD data published in 2013. In order to examine the employment effects, the global inverse Leontief matrix obtained from the world input-output table, the trade vector and Stehrer et al.'s (2012) labour coefficients were used. In Jiang's (2013) article, the employment effects arising from international trade of countries are aggregated. In this study, they are disaggregated by country and sector. The fourth section presents the results and policy recommendations. 
Savac1, S. \& A.D. Seymen (2020), "The Effect of International Trade

on Employment in Turkey", Sosyoekonomi, Vol. 28(44), 91-106.

\section{Literature Review: The Relationship between International Trade and Employment in Turkey}

Studies examining the effects of international trade on employment generally focus on the effects of the export and import of finished goods, including studies about Turkey. Günlük and Şenesen (1998) analysed the effect of export-oriented industrialisation on employment in Turkey using Turkey's 1973 and 1990 input-output tables. According to the results of this study, which analysed the forward and backward linkages of sectors, exportoriented industrialisation could not shift Turkey's production structure to the sectors that create more employment, in comparison to the import substitution process.

Erlat (2000) investigating the impact of international trade on employment between 1963-1994 in Turkey, addressed the impact of changes in the export and imports of manufacturing sector employment using a simple method of calculation. According to the results of this study, a significant part of the increase in employment after 1980, when the transition from import substitution to export-led growth strategy occurred, was due to an increase in exports.

Günçavdı and Küçükçiftçi (2001) using the 1990 input-output tables, measured the factor intensity in Turkey and investigated the level of cost reduction and saving of domestic production factors resulting from the intermediate inputs imported. According to this study, foreign trade in intermediate goods led to either savings or additional use of domestic production factors.

Ayaş and Çeştepe (2009) analysed the employment effect of international trade on manufacturing in Turkey using the 1998 and 2002 input-output tables for Turkey. Employment effect was examined in order to reveal any change in employment due to changes in foreign trade balances from 1998 to 2002. The employment effect of international trade differs according to sectors. The results showed that the employment effect mainly depends on the increase in import volumes. The chemical, rubber and plastics sectors showed the highest employment increase, while the import volume of these sectors rose 20 times during the research period. Therefore, Ayas and Cestepe's study supports the thesis that production and employment in manufacturing is highly dependent on imported inputs. The greatest loss of employment was in the food, beverage and tobacco sectors.

In another study, Saraçoğlu (2017) analysed the effects of increased trade between China and Turkey on Turkey's manufacturing sector employment and found that the trade imbalance between the two countries deteriorated continuously to the detriment of Turkey. The origins and effects of this trade balance on Turkey's economy was analysed using sectoral concentration, intra-industry trade, and factor content analysis. According to the results, the strongest negative employment effect was in high technology - office, accounting and information processing machines, medical and optical instruments and watch-making whose imports increased significantly in 2000s, while the weakest effect was in low technology - the clothing, textile and furniture sectors. However, in addition to the direct employment effects of foreign trade with China, the negative effect on the clothing and 
Savac1, S. \& A.D. Seymen (2020), "The Effect of International Trade on Employment in Turkey", Sosyoekonomi, Vol. 28(44), 91-106.

textile sectors becomes more important considering the indirect employment effects. While these studies are important in terms of showing the effects of final goods trade on employment, the employment gains or losses caused by the intermediate goods trade in international production chains was not examined.

During the literature review, three studies for Turkey using the WIOD database were found. The first is Gündoğdu and Saraçoğlu (2016), analysing Turkey's backward integration (vertical specialisation) to global value chains at the country and sectoral level. Comparison between 1995 and 2011 shows that Turkey's backward integration to GVCs increased in the medium-high and high technology sectors. At country level, Germany, China, Italy and France made the highest contribution to Turkey's backward integration. Since 2011, China has made the highest contribution to Turkey's backward integration in the low technology sectors. From these results, the authors recommended that instead of this kind of integration, Turkey has to target the high technology sector.

The second study is Gül and Çakaloğlu's (2017), which calculates output, income and employment multipliers and the forward and backward linkages of the construction sector between 2000 and 2014. From the results, the authors suggest that the construction sector has a limited impact on dragging the economy down and resources should be allocated to sectors that have a stronger backward-forward linkages to create value added and compete in the international market.

Stehrer et al. (2012) decomposed the value added and factor content of trade into foreign and domestic components. Using the World Input-Output Database (WIOD) covering 40 countries and 35 industries, the authors found that the domestic value-added content of exports tended to decrease from 1995 to 2009, the only increases being during periods of economic crises. Another result was that emerging economies generally export relatively more capital and import labour in value terms, while advanced economies follow the opposite pattern.

In Jiang's study (2013) which our study's methodology is based on, five effects of international trade on employment were identified by using the world input-output table for 2009 and for 39 countries, including Turkey. According to Jiang's results, the final goods trade of Turkey in 2009 created 5 million 203 thousand jobs, the intermediate goods trade created 968,8 thousand jobs, while 2 million 56 thousand domestic employment jobs resulted from exports, and 6,2 thousand domestic employment jobs resulted from the export content of imports. The foreign employment effects were that imports created 3 million 146 thousand posts, the import content of exports created 456 thousand jobs and imports from a third country created 506 thousand jobs. Turkey's international trade in 2009 resulted in creating 2 million 46 thousand more foreign jobs than domestic ones.

Kizu et al. (2019) examined countries whose demands support an increase in global supply chain (GSC) related jobs located elsewhere, and whether GSC linkages between countries and country groups have changed over time. The authors used data from the World Input-Output Database to examine linkages across 40 countries 1995-2013. According to 
the results, the export destinations where the demand for GSC-related goods and services originate, are sustained by countries in the European Union. Another result is that the most GSC-related jobs are located in emerging economies. These jobs are mainly in services, due to the servicification of manufacturing.

\section{Data and Methodology}

The aggregated results in Jiang (2013) were firstly analysed at the country level in this study. Since the employment data is missing from the WIOD database for Luxemburg, Malta and Russia for 2014, these countries could not be included in the analysis. For the sectoral data, some ISIC Rev 3 . sectors ${ }^{1}$ are missing, which means the inverse matrices could not be calculated. However, this study covers 40 countries and 38 sectors. Table 1 shows the countries and sectors included in the study.

Table: 1

\section{Sectors and Countries Covered in the Study}

\begin{tabular}{|c|c|c|}
\hline \multicolumn{2}{|c|}{ Sectors ISIC Rev. 4} & \multirow{2}{*}{$\begin{array}{l}\text { Countries } \\
\text { Australia }\end{array}$} \\
\hline A01 & Crop and animal production, hunting and related service activities & \\
\hline $\mathrm{A} 02$ & Forestry and logging & Austria \\
\hline $\mathrm{A} 03$ & Fishing and aquaculture & Belgium \\
\hline $\mathrm{B}$ & Mining and quarrying & Bulgaria \\
\hline $\mathrm{C} 10-\mathrm{C} 12$ & Manufacture of food products, beverages and tobacco products & Brazil \\
\hline $\mathrm{C} 13-\mathrm{C} 15$ & Manufacture of textiles, wearing apparel and leather products & Canada \\
\hline $\mathrm{C} 16$ & $\begin{array}{l}\text { Manufacture of wood and of products of wood and cork, except furniture; } \\
\text { manufacture of articles of straw and plaiting materials }\end{array}$ & Switzerland \\
\hline $\mathrm{C} 17$ & Manufacture of paper and paper products & China \\
\hline $\mathrm{C} 18$ & Printing and reproduction of recorded media & Cyprus \\
\hline $\mathrm{C} 19$ & Manufacture of coke and refined petroleum products & Czech Republic \\
\hline $\mathrm{C} 20$ & Manufacture of chemicals and chemical products & Germany \\
\hline $\mathrm{C} 22$ & Manufacture of rubber and plastic products & Denmark \\
\hline $\mathrm{C} 23$ & Manufacture of other non-metallic mineral products & Spain \\
\hline $\mathrm{C} 24$ & Manufacture of basic metals & Estonia \\
\hline $\mathrm{C} 25$ & Manufacture of fabricated metal products, except machinery and equipment & Finland \\
\hline $\mathrm{C} 26$ & Manufacture of computer, electronic and optical products & France \\
\hline $\mathrm{C} 27$ & Manufacture of electrical equipment & United Kingdom \\
\hline $\mathrm{C} 28$ & Manufacture of machinery and equipment n.e.c. & Greece \\
\hline $\mathrm{C} 29$ & Manufacture of motor vehicles, trailers and semi-trailers & Croatia \\
\hline $\mathrm{C} 30$ & Manufacture of other transport equipment & Hungary \\
\hline $\mathrm{C} 31-\mathrm{C} 32$ & Manufacture of furniture; other manufacturing & Indonesia \\
\hline
\end{tabular}

1 These sectors are: C21: Manufacture of basic pharmaceutical products and pharmaceutical preparations, C33: Repair and installation of machinery and equipment, E36: Water collection, treatment and supply, E37-39: Sewerage; waste collection, treatment and disposal activities; materials recovery; remediation activities and other waste management services, G45: Wholesale and retail trade and repair of motor vehicles and motorcycles, H53: Postal and courier activities, J58: Publishing activities, J59-60: Motion picture, video and television programme production, sound recording and music publishing activities; programming and broadcasting activities, K65: Insurance, reinsurance and pension funding, except compulsory social security, K66: Activities auxiliary to financial services and insurance activities, L68: Real estate activities, M69-70: Legal and accounting activities; activities of head offices; management consultancy activities, M71: Architectural and engineering activities; technical testing and analysis, M72: Scientific research and development, M73: Advertising and market research, M74-75: Other professional, scientific and technical activities; veterinary activities, T: Activities of households as employers; undifferentiated goods- and servicesproducing activities of households for own use and U: Activities of extraterritorial organizations and bodies. 
Savac1, S. \& A.D. Seymen (2020), "The Effect of International Trade on Employment in Turkey", Sosyoekonomi, Vol. 28(44), 91-106.

\begin{tabular}{|l|l|l|}
\hline D35 & Electricity, gas, steam and air conditioning supply & India \\
\hline F & Construction & Ireland \\
\hline G46 & Wholesale trade, except motor vehicles and motorcycles & Italy \\
\hline G47 & Retail trade, except motor vehicles and motorcycles & Japan \\
\hline H49 & Land transport and transport via pipelines & Korea \\
\hline H50 & Water transport & Lithuania \\
\hline H51 & Air transport & Latvia \\
\hline H52 & Warehousing and support activities for transportation & Mexico \\
\hline I & Accommodation and food service activities & Netherlands \\
\hline J61 & Telecommunications & Norway \\
\hline J62-J63 & Computer programming, consultancy and related activities; information service activities & \\
\hline K64 & Financial service activities, except insurance and pension funding & \\
\hline N & Administrative and support service activities & Poland \\
\hline O84 & Public administration and defence; compulsory social security & Portugal \\
\hline P85 & Education & Romania \\
\hline Q & Human health and social work activities & Slovakia \\
\hline R-S & Other service activities & Slovenia \\
\hline & & Sweden \\
\hline
\end{tabular}

After analysing the effect of Turkey's total international trade on employment in 2014, a country and sectoral analysis was carried out. The methodology consisted of the global Leontief inverse matrix, $\boldsymbol{L}^{\boldsymbol{G}}$, labour coefficients vector, $\boldsymbol{e}$, and the trade vector, $\boldsymbol{t}$. After explaining the methodology for a model with three countries (countries 1,2 and 3) without any sector distinction, analysis by sector was also done. Country 1 represents the home country and the global Leontief inverse matrix is obtained from the matrix of global input coefficients. The typical elements of the global input coefficients matrix are $\mathrm{A}^{\mathrm{ij}}$, the imported intermediate goods input coefficients, and $\mathrm{i}=\mathrm{j}$ gives the matrix of the domestic input coefficients. When a country's basic input-output relationship is expressed as $\mathrm{Y}=\mathrm{AY}+\mathrm{F}$, $\mathrm{A}$ is the input coefficient matrix, $\mathrm{Y}$ is the output vector and $\mathrm{F}$ is the final demand vector; the final demand of the countries in a three-country model with trade relations as follows (Jiang, 2013: 5):

$$
\begin{aligned}
& Y^{1}-A^{11} Y^{1}-A^{12} Y^{2}-A^{13} Y^{3}=f^{1} \\
& -A^{21} Y^{1}+Y^{2}-A^{22} Y^{2}-A^{23} Y^{3}=f^{2} \\
& -A^{31} Y^{1}-A^{32} Y^{2}+Y^{3}-A^{33} Y^{3}=f^{3}
\end{aligned}
$$

According to equation (1), the final demand for each country is the remainder from the total output of domestic and export intermediates. For example; $A^{11} Y^{1}$, shows the domestic intermediate goods for country 1 , and $\mathrm{A}^{12} \mathrm{Y}^{2}$, shows the export intermediates from country 1 to country 2 . The final demand equals the difference between output and intermediate product use. If equation (1) is expressed in matrix notation, the global input coefficients matrix is obtained.

$$
\left[\begin{array}{ccc}
I-A^{11} & -A^{12} & -A^{13} \\
-A^{21} & I-A^{22} & -A^{23} \\
-A^{31} & -A^{32} & I-A^{33}
\end{array}\right] \cdot\left[\begin{array}{c}
Y^{1} \\
Y^{2} \\
Y^{3}
\end{array}\right]=\left[\begin{array}{c}
f^{1} \\
f^{2} \\
f^{3}
\end{array}\right]
$$

"A", global input coefficients matrix, subtracted from the unit matrix, and taking the reciprocal, gives the global Leontief inverse matrix: 


$$
\boldsymbol{L}^{\boldsymbol{G}}=\left\{\left[\begin{array}{lll}
1 & 0 & 0 \\
0 & 1 & 0 \\
0 & 0 & 1
\end{array}\right]-\left[\begin{array}{ccc}
\mathrm{I}-\mathrm{A}^{11} & -\mathrm{A}^{12} & -\mathrm{A}^{13} \\
-\mathrm{A}^{21} & \mathrm{I}-\mathrm{A}^{22} & -\mathrm{A}^{23} \\
-\mathrm{A}^{31} & -\mathrm{A}^{32} & \mathrm{I}-\mathrm{A}^{33}
\end{array}\right]\right\}^{-1}=\left[\begin{array}{lll}
l^{11} & l^{12} & l^{13} \\
l^{21} & l^{22} & l^{23} \\
l^{31} & l^{32} & l^{33}
\end{array}\right]
$$

The global Leontief inverse matrix is $3 \times 3$ in the three-country non-sectoral model; to generalise, $\boldsymbol{L}^{\boldsymbol{G}}$ is an $\mathrm{n} \times \mathrm{n}$ dimensional matrix where $n=$ Country Number $x$ Sector Number. In two-digit indices, the first step is the country of origin, and the second step is the affected country.

The trade vector is shown as $\mathrm{t}^{\prime}=\left(\mathrm{x}^{1^{*}},-\mathrm{x}^{21},-\mathrm{x}^{31}\right) \cdot \mathrm{x}^{1^{*}}$ is the total exports of country 1 to the world and $x^{r 1}$ is the exports of country $r$ to country 1 . In other words, the import by the home country from country $r$, which takes place in the trade vector with a negative sign. The global Leontief inverse matrix multiplied by the trade vector gives the total international trade value of the home country. After this stage, the labour coefficients vector can be added to the analysis. The labour coefficients vector is expressed as $\mathrm{e}^{\prime}=\left(\mathrm{e}^{1}, \mathrm{e}^{2}, \mathrm{e}^{3}\right)$. For each country, the labour coefficient shows the level of labour required per unit of output. After creating the trade vector and labour coefficients vector diagonal matrices, the matrix from multiplying the global Leontief, trade and labour coefficients matrices gives the employment matrix of the home country $\left(E^{1}\right)$.

$$
E^{1}=e^{\prime} L^{G} t^{\prime}=\left[\begin{array}{ccc}
e^{1} & 0 & 0 \\
0 & e^{2} & 0 \\
0 & 0 & e^{3}
\end{array}\right]\left[\begin{array}{lll}
l^{11} & l^{12} & l^{13} \\
l^{21} & l^{22} & l^{23} \\
l^{31} & l^{32} & l^{33}
\end{array}\right]\left[\begin{array}{ccc}
x^{1 *} & 0 & 0 \\
0 & -x^{21} & 0 \\
0 & 0 & -x^{31}
\end{array}\right]
$$

In equation (4), the multiplication of the trade diagonal matrix with the global Leontief inverse matrix gives the total output caused by a certain amount of export demand. Since the labour coefficient also shows the amount of labour required per unit of output, multiplying the diagonal matrix of labour coefficients gives the labour needed for the output resulting from export demand. The five effects of international trade on the home country with countries 2 and 3 on employment can be read from the elements of the employment matrix (Stehrer et al., 2012: 4).

$$
E^{1}=\left[\begin{array}{lll}
e^{1} l^{11} x^{1 *} & -e^{1} l^{12} x^{21} & -e^{1} l^{13} x^{31} \\
e^{2} l^{21} x^{1 *} & -e^{2} l^{22} x^{21} & -e^{2} l^{23} x^{31} \\
e^{3} l^{31} x^{1 *} & -e^{3} l^{32} x^{21} & -e^{3} l^{33} x^{31}
\end{array}\right]
$$

The effects of international trade on employment by employment matrix:

- The employment effect of exports: $e^{1} l^{11} x^{1 *}$, shows the employment effect of country 1's total exports. When the home country is country 1 , the first diagonal element of the employment matrix gives the employment effect of total exports.

- The employment effect of imports is shown by $-e^{2} l^{22} x^{21}$ and $-e^{3} l^{33} x^{31}$, which give the employment effect of imports from countries 2 and 3 , respectively. The other diagonal elements of the employment matrix give the employment effect of total imports. Thus, the traditional effects of international trade on employment 
can be determined. Subsequent effects are due to employment resulting from the intermediate goods trade in international production chains.

- The employment effect of the import content of exports: is indicated by $e^{2} l^{21} x^{1 *}$ and $e^{3} l^{31} x^{1 *}$ (except the element showing the employment effect of exports in the first column), showing the effect of the intermediate imports from countries 2 and 3 used in exports by country 1 , on employment. $e^{2} l^{21} x^{1 *} ; l^{21}$, is the total value created in country 2 , due to country 1 's import demand from country 2 . When this value is multiplied by $x^{1 *}$, the result gives the total value created in country 2 resulting from country 1 's exports. Finally, multiplying this value with the labor coefficient for country $2 e^{2}$, gives the employment level needed to produce the total value in country 2 generated by country 1 's exports.

- The employment effect of the export content of imports is represented by $-e^{1} l^{12} x^{21}$ and $-e^{1} l^{13} x^{31}$ (except the element showing the employment effect of exports in the first row), which shows the effect of the exports of country 1 including the imports from countries 2 and 3 In other words, this is the employment effect of re-exports on country 1 .

- Concerning the employment effect of imports from third countries, $-e^{2} l^{23} x^{31}$ and $-e^{3} l^{32} x^{21}$ (except the column and row showing the employment effect of exports and diagonal matrix) shows the employment effect of imports from third countries. For example; $-e^{2} l^{23} x^{31}$ is the effect of the intermediate goods imported from a second country on the second country's employment, from the export of the third country to the first country.

The effects of foreign trade on employment in a three-country model have been outlined above. In this study, as 40 countries are considered, the employment matrix for the whole economy is $40 \mathrm{x} 40$. The elements of the employment matrix show results at the country level. When $\boldsymbol{a}$ is the home country, $\boldsymbol{p}$ is the partner country and $\boldsymbol{q}$ is the third country, the total effects are as follows:

- The employment effect of exports: $\mathrm{e}^{\mathrm{a}} \mathrm{l}^{\mathrm{aa}} \mathrm{x}^{\mathrm{a}}$

- The employment effect of imports: $\sum_{p}(p \neq a) e^{p} 1^{p p} x^{p a}$

- The employment effect of import content of exports: $\sum p(p \neq a) e^{p} p^{p a} x^{a}$

- The employment effect of export content of imports: $\sum_{p}(p \neq a) e^{a} 1^{a p} x^{p a}$

- The employment effect of import from third countries: $\sum_{p, q}(p \neq q ; p, q \neq a) e^{q} 1^{q p} x^{p a}$

In order to examine the sectoral effects after the effects at the total and country level have been outlined, the matrix needs to be rearranged to cover the sectors. The arrangement is made as shown in Stehrer et al (2012). When the method for the whole economy introduced, it was stated that the global Leontief inverse matrix, $\boldsymbol{L}^{\boldsymbol{G}}$, is an $\mathrm{n} \times \mathrm{n}$ dimensional 
matrix where $n=$ Country Number $x$ Sector Number. In a model with three countries and two sectors, $\boldsymbol{L}^{\boldsymbol{G}}$ and the employment matrix is $6 \times 6$.

$$
\mathrm{E}=\left[\begin{array}{lllll}
e_{1}^{1} l_{11}^{11} x_{1}^{1 *} & e_{1}^{1} l_{12}^{11} x_{2}^{1 *} & e_{1}^{1} l_{11}^{12} x_{1}^{2 *} e_{1}^{1} l_{12}^{12} x_{2}^{2 *} & e_{1}^{1} l_{11}^{13} x_{1}^{3 *} & e_{1}^{1} l_{12}^{13} x_{2}^{3 *} \\
e_{2}^{1} l_{21}^{11} x_{1}^{1 *} & e_{2}^{1} l_{22}^{11} x_{2}^{1 *} & e_{2}^{1} l_{21}^{12} x_{1}^{2 *} e_{2}^{1} l_{22}^{12} x_{2}^{2 *} & e_{2}^{1} l_{21}^{13} x_{1}^{3 *} & e_{2}^{1} l_{22}^{13} x_{2}^{3 *} \\
e_{1}^{2} l_{11}^{21} x_{1}^{1 *} & e_{1}^{2} l_{12}^{21} x_{2}^{1 *} & e_{1}^{2} l_{11}^{22} x_{1}^{2 *} e_{1}^{2} l_{12}^{22} x_{2}^{2 *} & e_{1}^{2} l_{11}^{23} x_{1}^{3 *} & e_{1}^{2} l_{12}^{23} x_{2}^{3 *} \\
e_{2}^{2} l_{21}^{21} x_{1}^{1 *} & e_{2}^{2} l_{22}^{21} x_{2}^{1 *} & e_{2}^{2} l_{21}^{22} x_{1}^{2 *} e_{2}^{2} l_{22}^{22} x_{2}^{2 *} & e_{2}^{2} l_{21}^{23} x_{1}^{3 *} & e_{2}^{2} l_{22}^{23} x_{2}^{3 *} \\
e_{1}^{3} l_{11}^{31} x_{1}^{1 *} & e_{1}^{3} l_{12}^{31} x_{2}^{1 *} & e_{1}^{3} l_{11}^{32} x_{1}^{2 *} e_{1}^{3} l_{12}^{32} x_{2}^{2 *} & e_{1}^{3} l_{11}^{33} x_{1}^{3 *} & e_{1}^{3} l_{12}^{33} x_{2}^{3 *} \\
e_{2}^{3} l_{21}^{31} x_{1}^{1 *} & e_{2}^{3} l_{22}^{31} x_{2}^{1 *} & e_{2}^{3} l_{21}^{32} x_{1}^{2 *} e_{2}^{3} l_{22}^{32} x_{2}^{2 *} & e_{2}^{3} l_{21}^{33} x_{1}^{3 *} & e_{2}^{3} l_{22}^{33} x_{2}^{3 *}
\end{array}\right]
$$

In the employment matrix by sectors, the subscripts refer to sectors and superscripts refer to countries. As mentioned before, in two-digit indices, the first step is the country of origin, and the second step is the affected country. For example, in $e_{1}^{1} l_{11}^{11} x_{1}^{1 *}, e_{1}^{1}$ is the employment level of country 1 in sector one. $l_{11}^{11}$, is obtained from $A_{11}^{11}$, which is the inputs from sector one to sector one in country $1 . x_{1}^{1 *}$ shows the sector one exports of country 1 (Stehrer et al., 2012: 7). When the 38 sectors examined in the study are added in, the employment matrix dimension is $1520 \times 1520$.

\section{Results}

Table 2 shows five different employment effects of international trade on Turkey. In 2014, Turkey's international trade resulted in 2,9 million domestic jobs and 1298 foreign jobs. International trade created more domestic than foreign jobs; in addition, the final goods trade created more employment than trade resulting from intermediate goods. Domestic employment demand was to 20,2\% of Turkey's total employment in 2014.

Table: 2

Total Employment Effect of International Trade in Turkey, 2014

\begin{tabular}{|c|c|c|}
\hline & & Total Employment (persons) \\
\hline \multirow{2}{*}{ Domestic Employment } & The employment effect of exports & $2.951 .819,8$ \\
\hline & The employment effect of export content of imports & $1.298,8$ \\
\hline \multirow{3}{*}{ Foreign Employment } & The employment effect of imports & $417.674,5$ \\
\hline & The employment effect of import content of exports & 831,7 \\
\hline & The employment effect of import from third countries & $859.242,0$ \\
\hline \multicolumn{2}{|c|}{ Domestic Employment - Foreign Employment } & $1.725 .280,1$ \\
\hline \multicolumn{2}{|l|}{ Final Goods Trade } & $2.621 .508,8$ \\
\hline \multicolumn{2}{|c|}{ Intermediate Goods Trade } & $861.372,5$ \\
\hline
\end{tabular}

Source: WIOT database and authors' calculations.

When compared with Jiang's (2013) results, it can be said that foreign trade created more employment in Turkey in 2014 than in 2009. In 2014, the effect of exports on domestic job creation increased by $43,5 \%$. Another point is that the employment effect of imports from third countries doubled, which means that Turkey's imports are also highly dependent on imports from other countries, which also means that these goods go through at least two production stages before Turkey imports them. Overall, Turkey's international created more domestic employment than foreign employment in 2014, in contrast to 2009. The reason for this change is mainly a decrease in the foreign employment effect of imports. 
The employment effect of exports at the country level shows that exports to Germany, United States, Italy, United Kingdom and France created the highest level of (domestic) employment in Turkey. This result is mostly in parallel with Turkey's top five export partners in 2014, namely Germany, Iraq, United Kingdom, Italy and France. Since the WIOD does not contain information about Iraq, we do not have any information about the employment effect of trade with Iraq.

Turkey's import demand resulted in the highest level of foreign employment in India, China, Indonesia, Brazil and Germany in 2009. However, in 2014, India, Indonesia and Brazil are not listed in the top twenty import partners of Turkey. This result shows that even if these countries are not Turkey's most important import partners, the imported goods from these countries are highly labour intensive, which is why they create the highest employment levels in those countries.

Table: 3

\section{Employment Effect of International Trade with Countries*}

\begin{tabular}{|c|c|c|c|c|c|c|c|}
\hline & \multicolumn{2}{|c|}{ Domestic Employment (persons) } & \multicolumn{3}{|c|}{ Foreign Employment (persons) } & \multirow{2}{*}{$\begin{array}{c}\text { Domestic } \\
\text { Employment - } \\
\text { Foreign } \\
\text { Employment }\end{array}$} & \multirow{2}{*}{$\begin{array}{c}\text { Final Goods Trade } \\
\text { Employment - } \\
\text { Intermediate Goods } \\
\text { Trade Employment } \\
\text { (persons) }\end{array}$} \\
\hline & $\begin{array}{l}\text { The employment } \\
\text { effect of exports }\end{array}$ & $\begin{array}{l}\text { The employment } \\
\text { effect of the export } \\
\text { content of imports }\end{array}$ & $\begin{array}{l}\text { The employment } \\
\text { effect of imports }\end{array}$ & $\begin{array}{l}\text { The employment } \\
\text { effect of the import } \\
\text { content of exports }\end{array}$ & $\begin{array}{l}\text { The employment } \\
\text { effect of imports } \\
\text { from third countries }\end{array}$ & & \\
\hline Germany & $415.544,0$ & 284,1 & $13.242,4$ & 351,7 & $27.939,5$ & $374.294,5$ & $400.211,1$ \\
\hline United States & $221.947,8$ & 13,3 & $3.204,1$ & 21,1 & $6.765,8$ & $211.970,1$ & $218.351,7$ \\
\hline Italy & $199.770,1$ & 193,2 & $8.343,8$ & 77,9 & $17.407,0$ & $174.134,6$ & $190.435,8$ \\
\hline U. Kingdom & $151.127,0$ & 54,2 & $2.235,4$ & 17,6 & $4.762,3$ & $144.165,9$ & $148.528,3$ \\
\hline France & $150.849,8$ & 79,0 & $3.998,8$ & 21,8 & $8.547,4$ & $138.360,8$ & $146.200,4$ \\
\hline Spain & $120.832,9$ & 105,6 & $3.553,5$ & 18,3 & $7.451,1$ & $109.915,6$ & $116.811,4$ \\
\hline China & $97.405,7$ & 7,7 & $84.448,5$ & 159,9 & $175.907,1$ & $-163.102,0$ & $5.779,5$ \\
\hline Romania & $75.758,4$ & 51,0 & $11.051,0$ & 13,2 & $22.551,5$ & $42.193,7$ & $64.193,7$ \\
\hline Belgium & $74.414,7$ & 42,0 & 940,8 & 3,3 & $2.069,8$ & $71.442,8$ & $73.240,4$ \\
\hline Netherlands & $59.546,1$ & 26,5 & 961,2 & 2,8 & $2.233,6$ & $56.375,0$ & $58.244,4$ \\
\hline Bulgaria & $58.378,4$ & 201,7 & $10.024,0$ & 10,0 & $20.268,8$ & $28.277,3$ & $47.921,9$ \\
\hline Poland & $57.711,8$ & 31,3 & $4.012,4$ & 15,5 & $8.859,8$ & $44.855,4$ & $52.817,6$ \\
\hline Canada & $50.963,8$ & 1,8 & 453,0 & 1,2 & $1.073,0$ & $49.438,4$ & $50.340,8$ \\
\hline Brazil & $46.004,4$ & 3,6 & $14.054,0$ & 5,7 & $29.020,9$ & $2.927,4$ & $31.028,2$ \\
\hline India & $37.973,1$ & 8,4 & $145.168,9$ & 65,3 & $294.581,7$ & $-401.834,3$ & $-111.513,3$ \\
\hline Greece & $37.314,2$ & 50,4 & $3.374,4$ & 3,4 & $6.813,7$ & $27.173,1$ & $33.821,1$ \\
\hline Indonesia & $35.791,5$ & 13,4 & $81.485,8$ & 27,0 & $164.580,7$ & $-210.288,5$ & $-47.343,7$ \\
\hline Austria & $31.620,7$ & 19,7 & 841,7 & 1,1 & $1.894,3$ & $28.903,3$ & $30.547,3$ \\
\hline Sweden & $30.306,7$ & 7,7 & 631,3 & 0,9 & $1.399,1$ & $28.283,1$ & $29.530,3$ \\
\hline Hungary & $26.141,6$ & 13,0 & $1.326,8$ & 2,4 & $2.952,6$ & $21.872,8$ & $24.500,4$ \\
\hline $\begin{array}{l}\text { Czech } \\
\text { Republic }\end{array}$ & $25.633,4$ & 25,4 & $2.547,4$ & 3,5 & $5.602,0$ & $17.505,9$ & $22.549,9$ \\
\hline Switzerland & $24.518,3$ & 18,2 & 635,9 & 0,8 & $1.375,3$ & $22.524,5$ & $23.759,9$ \\
\hline Denmark & $23.707,5$ & 3,9 & 216,2 & 0,1 & 480,8 & $23.014,3$ & $23.438,9$ \\
\hline $\begin{array}{l}\text { Republic of } \\
\text { Korea }\end{array}$ & $18.579,2$ & 7,9 & $5.667,9$ & 2,7 & $11.836,2$ & $1.080,3$ & $12.400,3$ \\
\hline Portugal & $17.911,2$ & 7,9 & $1.018,9$ & 0,9 & $2.198,7$ & $14.700,6$ & $16.722,6$ \\
\hline Mexico & $17.134,1$ & 0,6 & $5.145,6$ & 0,5 & $10.463,5$ & $1.525,1$ & $11.815,1$ \\
\hline Australia & $16.869,0$ & 1,4 & 369,5 & 0,3 & 809,4 & $15.691,2$ & $16.427,4$ \\
\hline Slovakia & $11.833,5$ & 6,9 & 665,3 & 0,7 & $1.506,7$ & $9.667,7$ & $10.984,5$ \\
\hline Finland & $10.408,4$ & 6,1 & 528,3 & 0,2 & $1.113,7$ & $8.772,3$ & $9.816,7$ \\
\hline Ireland & $10.363,1$ & 0,7 & 99,1 & 0 & 231,5 & $10.033,2$ & $10.230,0$ \\
\hline Japan & $10.329,4$ & 0,8 & $1.714,4$ & 0,9 & $4.131,2$ & $4.483,7$ & $7.910,9$ \\
\hline Norway & $9.392,3$ & 1,7 & 262,7 & 0,1 & 570,0 & $8.561,2$ & $9.083,2$ \\
\hline Taiwan & $7.326,2$ & 3,1 & 417,1 & 1 & $9.079,5$ & $-5.922,1$ & $2.413,6$ \\
\hline Slovenia & $6.529,6$ & 3,0 & 278,2 & 0,1 & 619,9 & $5.634,4$ & $6.184,8$ \\
\hline Croatia & $5.249,9$ & 0,6 & 245,1 & 0 & 539,9 & $4.465,5$ & $4.954,5$ \\
\hline Lithuania & $3.598,4$ & 0,9 & 438,5 & 0 & 917,3 & $2.243,5$ & $3.118,7$ \\
\hline Estonia & $2.641,2$ & 1,5 & 105,5 & 0 & 231,4 & $2.305,8$ & $2.513,8$ \\
\hline Latvia & $2.330,3$ & 0,3 & 212,8 & 0 & 448,8 & $1.669,0$ & $2.094,0$ \\
\hline Cyprus & 74,8 & 0 & 0,6 & 0 & 6,4 & 67,8 & 69,1 \\
\hline
\end{tabular}

Source: WIOT database and authors' calculation.

* Countries are ranked according to their total domestic employment effect.

According to the findings, the employment effect of the intermediate goods trade is generally much less than the effect of the final goods trade. Table 3 shows that the countries 
Savac1, S. \& A.D. Seymen (2020), "The Effect of International Trade on Employment in Turkey", Sosyoekonomi, Vol. 28(44), 91-106.

with the highest employment effects do not change dramatically within the domestic and foreign employment categories. The last column of Table 3 shows the difference between the employment effects of the final goods and intermediate goods trades by country. The results show that trade resulting from the trade in intermediate goods created more employment in India and Indonesia; this may mean that Turkey's international trade with India and Indonesia is highly dependent on the intermediate goods trade. By contrast, the final goods trade with Germany has a higher employment effect than the intermediate goods trade.

The comparison between domestic and foreign employment shows that international trade with India, Indonesia and China created more foreign employment than domestic employment in Turkey. On the other hand, international trade with Germany, United States and Italy created higher domestic employment than foreign employment. These results led us to research the countries listed above in more detail. The results of the sectoral analysis are given in detail. Country tables in the annexes contain all five categories except the employment effect of exports, so the results should be interpreted with care. This method does not allow us to disaggregate the employment effect of exports by country and sector at the same time. Tables for those countries can be found in the annexes.

China: Turkey's textile and apparel imports created 46 thousand jobs in China, and is the highest employment effect. Turkey's imports in the computer, electronics and optical products manufacturing sector created 11 thousand jobs in China. From the domestic employment aspect, there is only the employment effect of the export content of imports seen in Table 3, but Turkey's exports to China have very little employment effect. The third country employment effect is only 2384 people in crop and animal production, hunting and related services.

India has nearly the same results as China. Textile and apparel imports into Turkey from India created 59 thousand jobs in India. An important point is that imports in crop and animal production, hunting and related services also has a significant employment effect in India (57 thousand jobs). As in China, Turkey's exports to India have a small employment effect, only on the export content of imports. The employment effect of imports from third countries is the highest on crop and animal production, hunting and related services sector, with 6320 jobs. In addition, one service sector, water transportation, has the second highest employment effect (1726 jobs) in terms of third country effect.

Indonesia has the highest employment effect in the textile and apparel sector, with 62 thousand jobs. Again, the crop, animal production and hunting sector is the second most important sector in terms of creating jobs abroad and third country effect.

Germany: the manufacture of motor vehicles, chemicals and chemical products and basic metals imports into Turkey from Germany resulted in 2228, 1592 and 1457 jobs, respectively. These are the sectors with the highest effects; however, it should be noted that the total employment effect of imports into Germany is equal to 13,4 thousand jobs, which is far from the effect of just the textile and apparel sector in China, India and Indonesia. In 
terms of exports, textile and apparel has the highest employment effect with 94 jobs, followed by the manufacture of motor vehicles, trailers and semi-trailers sector ( 53 jobs) and the manufacture of basic metals sector ( 51 jobs).

The United States: crop and animal production, hunting and related services sector has the highest employment effect in the US created by Turkey's imports from USA in this sector, 1022 jobs, after which, the manufacture of food products, beverages and tobacco products come second. Turkey's total exports to the US resulted in 23 jobs in total, which is a very small number; but it should be remembered that the employment effect of exports is not shown in these tables.

In Italy, the textile and apparel sector created the highest employment with 3367 jobs, followed by motor vehicles, trailers and semi-trailers, basic metals and machinery and equipment manufacturing n.e.c. sectors, which created 709, 635 and 613 jobs, respectively. For domestic employment, textile and apparel comes first again with 119 jobs in Turkey; but the effect is far lower than the employment effect in Italy.

\section{Conclusion}

In this study, the effect of international trade on employment in five categories was interpreted for Turkey for 2014 using Stehrer et al. (2012) and Jiang's (2013) methodologies. These five categories for employment are important because they show the changing nature of international trade, and that international trade is highly dependent on the intermediate goods trade.

The results indicate that one fifth of Turkey's total employment was generated from exports and the export content of imports in 2014. In addition, Turkey continues to be highly dependent on traditional trade categories for employment creation. In terms of domestic and foreign employment, the textile and apparel sector is at the forefront for nearly all countries. Another point is that Turkey's top five export partners are generally the top five domestic employment creators for Turkey; this shows a direct linkage between export volume and domestic employment, which leads us to the result that these exports are highly labour intensive. Increasing export volumes is dependent on increasing labour employment in Turkey. Turkey's international trade with China, India, Indonesia and Taiwan creates more employment abroad than in Turkey. In addition, the international trade with India and Indonesia is more dependent on the intermediate goods trade than the final goods trade.

The international structure of production is revealed in the numbers of the "employment effect of imports from third countries", which has increased by 71 percent in five years. Both main (in terms of creating foreign employment) final goods import partners, and also third country import partners are the same: China, India and Indonesia. This result shows that Turkey also promotes poor work conditions in Asian countries, by mainly creating the highest employment in those countries through importing from them. It is possible to turn this result inside out in the relationship between Turkey and European Union countries. For policy implications, these five effects of international trade have to be 
considered when determining employment policies. Policies that will reduce import dependency and increase intermediate goods production will also have an increasing effect on domestic employment demand. It is also questionable to what extent individual countries can change their production structures through their economic policies in such an intertwined world.

Also, further research needs to be done to eliminate the shortcomings of the methodology. In this way, some effects of international trade on domestic production and employment (e.g. the indirect domestic labour demand effects of intermediate goods imported for the domestic production and the consumption of industrial goods) that cannot be identified within this method, could be discovered.

\section{References}

Ayaş, N. \& H. Çeştepe (2010), "Dış Ticaretin İstihdam Üzerindeki Etkileri: Türk İmalat Sanayi Örneği”, Suleyman Demirel University The Journal of Faculty of Economics and Administrative Science, 15(2), 259-281.

Erlat, G. (2000), "Measuring the Impact of Trade Flows on Employment in the Turkish Manufacturing Industry", Applied Economics, 2000(32), 1169-1180.

Gül, Z.B. \& M. Çakaloğlu (2017), "İnşaat Sektörünün Dinamikleri: Türkiye için 2000-2014 GirdiÇıktı Analizi”, Akdeniz Üniversitesi İktisadi ve İdari Bilimler Fakültesi Dergisi, 17(36), 130-155.

Günçavd1, Ö. \& S. Küçükçiftçi (2001), "Foreign Trade and Factor Intensity in an Open Developing Country: An Input - Output Analysis for Turkey", Russian and East European Finance and Trade, 37(1).

Gündoğdu, C. \& D.Ş. Saraçoğlu (2016), "Participation of Turkey in Global Value Chains: An Analysis Based on World Input Output Database", ERC Working Paper Series in Economics, 16/10.

Günlük-Şenesen, G. (1998) “An Input-Output Analysis of Employment Structure in Turkey:19731990”, Economic Research Forum, Egypt, Working Paper Series, No: 9809.

Jiang, X. \& W. Milberg (2013), "Capturing the jobs from globalization: trade and employment in global value chains", Capturing The Gains Working Paper, No: 30.

Jiang, X. (2013), “Trade and Employment in a Vertically Specialized World”, ILO Working Paper, No. 5.

Kizu, T. \& S. Kühn \& C. Viegelahn (2019), "Linking jobs in global supply chains to demand", International Labour Review, 158(2), 213-244.

Saraçoğlu, D.Ş. (2017), "Çin Halk Cumhuriyeti ile Türkiye Arasında Dış Ticaretin Gelişimi ve Türkiye'de İmalat Sanayinde Sektörel İstihdama Etkisi”, Ankara Üniversitesi SBF Dergisi, 72(1), 151-182.

Stehrer, R. \& N. Foster \& G.J. de Vries (2012), "Value Added and Factors in Trade: A Comprehensive Approach", WIIW Working Paper Series, No. 80, 1-22.

Timmer, M.P. \& E. Dietzenbacher \& B. Los \& R. Stehrer \& G.J. de Vries (2015), “An Illustrated User Guide to the World Input-Output Database: the Case of Global Automotive Production", Review of International Economics, 23(3), 575-605. 
Annex: 1

\begin{tabular}{|c|c|c|c|c|c|c|c|c|c|c|c|c|c|c|}
\hline \multirow{3}{*}{$\begin{array}{c}\text { ISIC } \\
\text { Rev. 4* }\end{array}$} & \multirow{3}{*}{$\begin{array}{c}\begin{array}{c}\text { Domestic } \\
\text { Employment } \\
\text { (persons) }\end{array} \\
\text { The employment } \\
\text { effect of export } \\
\text { content of } \\
\text { imports }\end{array}$} & \multicolumn{3}{|c|}{ China } & \multirow{3}{*}{$\begin{array}{c}\text { Sectors } \\
\text { ISIC } \\
\text { Rev. 4* }\end{array}$} & \multirow{3}{*}{$\begin{array}{c}\begin{array}{c}\text { Domestic } \\
\text { Employment } \\
\text { (persons) }\end{array} \\
\text { The employment } \\
\text { effect of export } \\
\text { content of } \\
\text { imports } \\
\end{array}$} & \multicolumn{3}{|c|}{ India } & \multirow{3}{*}{\begin{tabular}{|c|} 
Sectors \\
ISIC \\
Rev. 4* \\
\end{tabular}} & \multirow{3}{*}{$\begin{array}{c}\begin{array}{c}\text { Domestic } \\
\text { Employment } \\
\text { (persons) }\end{array} \\
\text { The employment } \\
\text { effect of export } \\
\text { content of } \\
\text { imports }\end{array}$} & \multicolumn{3}{|c|}{ Indonesia } \\
\hline & & & $\begin{array}{l}\text { Foreign Employn } \\
\text { (persons) }\end{array}$ & & & & & $\begin{array}{l}\text { Foreign Employm } \\
\text { (persons) }\end{array}$ & & & & & $\begin{array}{l}\text { Foreign Employm } \\
\text { (persons) }\end{array}$ & \\
\hline & & $\begin{array}{c}\text { The } \\
\begin{array}{c}\text { employment } \\
\text { effect of } \\
\text { imports }\end{array} \\
\end{array}$ & $\begin{array}{c}\text { The employment } \\
\text { effect } \\
\text { of import content } \\
\text { of exports }\end{array}$ & \begin{tabular}{|c|} 
The employment \\
effect \\
of import from third \\
countries
\end{tabular} & & & $\begin{array}{c}\text { The } \\
\text { employment } \\
\text { effect of } \\
\text { imports }\end{array}$ & $\begin{array}{c}\text { The employment } \\
\text { effect } \\
\text { of import content } \\
\text { of exports }\end{array}$ & $\begin{array}{c}\text { The employment } \\
\text { effect } \\
\text { of import from third } \\
\text { countries }\end{array}$ & & & $\begin{array}{c}\text { The } \\
\text { employment } \\
\text { effect of } \\
\text { imports }\end{array}$ & $\begin{array}{c}\text { The employment } \\
\text { effect } \\
\text { of import content } \\
\text { of exports }\end{array}$ & \begin{tabular}{|c|c|c|} 
The employment \\
effect \\
of import from third \\
countries
\end{tabular} \\
\hline $\begin{array}{l}\text { C13-- } \\
\text { C15 }\end{array}$ & 4.63 & $45,459.86$ & 7894 & 84869 & $\begin{array}{l}\text { C13- } \\
\text { C15 }\end{array}$ & 2.11 & $58,432.24$ & 21.75 & 928.72 & $\begin{array}{l}\text { C13- } \\
\text { C15 }\end{array}$ & 9.04 & $62,299.76$ & 18.36 & 5.32 \\
\hline $\mathrm{C} 26$ & 005 & 11,8793 & 3.28 & 75.59 & A01 & 0.95 & $51,102.57$ & 17.39 & $6,320.80$ & A01 & 3.40 & $5,133.73$ & 4.27 & $4,732.03$ \\
\hline C20 & 0.72 & $4,930.56$ & 33.38 & 146.34 & C20 & 0.45 & $7,451.36$ & 5.29 & 134.66 & $\begin{array}{l}\text { C10- } \\
\text { C12 }\end{array}$ & 0.37 & $3,384.12$ & 2.32 & 34.39 \\
\hline A01 & 0.33 & $1,531.55$ & 8.05 & 2.384 .64 & $\mathrm{C}_{29}$ & 0.92 & $4,235.28$ & 4.15 & 15.91 & $\mathrm{C24}$ & 0.01 & $1,674.51$ & 0.18 & 1.85 \\
\hline C28 & 0.49 & $2,729.98$ & 7.64 & 324.74 & $\begin{array}{l}\mathrm{C} 10- \\
\mathrm{C} 12\end{array}$ & 0.02 & $3,231.32$ & 0.74 & 366.51 & C20 & 0.21 & $1,134.11$ & 0.61 & 10.93 \\
\hline $\begin{array}{l}\text { C27 } \\
\end{array}$ & 0.04 & $\begin{array}{l}2,236.38 \\
15578 \\
\end{array}$ & 2.10 & $\begin{array}{l}156.10 \\
8517\end{array}$ & $C_{C 24}$ & 1.0 & \begin{tabular}{|l|l|}
$2,355.17$ \\
170192
\end{tabular} & 5.38 & 43.33 & $\mathrm{C}_{22}$ & 0.03 & $\begin{array}{l}1,051.50 \\
1.050\end{array}$ & 0.33 & 11.44 \\
\hline $\begin{array}{l}\mathrm{C} 24 \\
\mathrm{C} 22 \\
\end{array}$ & $\begin{array}{l}0.31 \\
0.15 \\
\end{array}$ & $\begin{array}{l}1,554.78 \\
1,059.85 \\
\end{array}$ & $\begin{array}{l}4.94 \\
4.47\end{array}$ & $\begin{array}{r}87.47 \\
433.31 \\
\end{array}$ & $\begin{array}{l}\text { C16 } \\
\mathrm{H} 49 \\
\end{array}$ & 0.01 & $\begin{array}{c}1,704.82 \\
7.33 \\
\end{array}$ & $\frac{0.09}{2.88}$ & $\frac{107.43}{1,726.69}$ & $\begin{array}{l}\text { Cl7 } \\
\text { C16 }\end{array}$ & $\begin{array}{l}0.01 \\
0.0\end{array}$ & $\begin{array}{l}851.68 \\
372.62 \\
\end{array}$ & $\begin{array}{l}0.01 \\
0.01 \\
\end{array}$ & $\begin{array}{l}1.82 \\
1.96 \\
\end{array}$ \\
\hline $\mathrm{C} 23$ & 0.04 & $1,316.49$ & 1.62 & 38.66 & $\mathrm{C} 23$ & 0.04 & $1,457.84$ & 0.32 & 40.95 & $\begin{array}{l}\mathrm{C}_{\mathrm{C}} 31- \\
\mathrm{Cu}^{2}\end{array}$ & 0.01 & 124.66 & 0.01 & 1.71 \\
\hline C29 & 0.20 & $1,053.27$ & 2.62 & 38.11 & $F$ & 0.05 & 0 & 1.31 & 809.79 & $\mathrm{C}_{23}$ & 0.01 & 93.50 & 0.01 & 1.00 \\
\hline $\begin{array}{l}\mathrm{C} 17 \\
\mathrm{C10}-\end{array}$ & 0.00 & 962.18 & 0.23 & 23.42 & C22 & 0.16 & 506.08 & 0.49 & 168.06 & C29 & 0.01 & 86.35 & 0.01 & 2.80 \\
\hline $\begin{array}{l}\text { C10- } \\
\text { C12 }\end{array}$ & 0.02 & 617.32 & 0.34 & 223.55 & в & 0.99 & 2.15 & 0.22 & 597.18 & G46 & 0.02 & 0 & 0.12 & 80.00 \\
\hline $\begin{array}{l}\mathrm{C} 331- \\
\mathrm{C} 32\end{array}$ & 0.01 & 723.58 & 0.12 & $\begin{array}{l}94.18 \\
\end{array}$ & C28 & 0.24 & 488.02 & 0.93 & 51.06 & $\mathrm{I}$ & 0.03 & 0 & 0,05 & 68.69 \\
\hline $\begin{array}{ll}252 \\
\mathrm{C} 16\end{array}$ & 0.01 & 593.31 & 0.17 & 25.70 & G47 & 0.15 & 0 & 0.25 & 526.63 & H49 & 0.01 & 7.47 & 0.01 & 49.20 \\
\hline C25 & 0.03 & 386.68 & 0.79 & 129.69 & $\begin{array}{l}\mathrm{C}_{\mathrm{C}} 31-\mathrm{-} \\
\mathrm{C} 2\end{array}$ & 0.01 & 318.52 & 1.21 & 148.79 & G47 & 0.01 & 0 & 0.04 & 56.49 \\
\hline G46 & 0.07 & 0 & 0.54 & 485.59 & $\begin{array}{l}.52 \\
\mathrm{C} 27 \\
\end{array}$ & 0.01 & 379.74 & 0.15 & 18.92 & $\begin{array}{c}\mathrm{C} 26 \\
\end{array}$ & 0.00 & 49.63 & 0.01 & 0.18 \\
\hline $\begin{array}{c}\text { B } \\
\text { C18 }\end{array}$ & $\frac{0.22}{0.01}$ & $\begin{array}{l}\frac{13.92}{30.941} \\
\end{array}$ & $\frac{6.98}{0.04}$ & $\frac{327.24}{9.36}$ & $\begin{array}{l}\text { G446 } \\
\text { C19 }\end{array}$ & 0.0 .22 & $\frac{0}{322.78}$ & $\frac{0.09}{1.81}$ & $\frac{397.36}{1.89}$ & $\begin{array}{l}\mathrm{F} \\
\mathrm{C25}\end{array}$ & $\frac{0.01}{0.00}$ & $\frac{0}{14.04}$ & 0.09 & $\frac{22.79}{7.31}$ \\
\hline H49 & 0.09 & $\begin{array}{l}9.76 \\
9.76\end{array}$ & 0.049 & 298.33 & C17 & 0.00 & $\frac{32.27}{127.53}$ & $\frac{1.81}{0.02}$ & $\begin{array}{r}1.89 \\
20.91 \\
\end{array}$ & $\begin{array}{l}253 \\
\mathrm{C} 27\end{array}$ & $\frac{0.00}{0.00}$ & $\frac{14.04}{19.40}$ & 0.011 & $\begin{array}{l}7.31 \\
0.41\end{array}$ \\
\hline $\mathbf{F}$ & 0.04 & 0 & $\begin{array}{l}0.46 \\
\end{array}$ & 196.46 & C25 & 0.04 & 74.69 & 0.36 & 52.93 & $\mathbf{B}$ & 0.08 & $\frac{19.40}{0.00}$ & 0.27 & $\begin{array}{l}0.41 \\
14.63\end{array}$ \\
\hline G47 & 0.09 & 0 & 0.02 & 180.09 & C18 & 0.00 & 115.65 & 0.00 & 6.45 & H50 & 0.00 & 13.25 & 0.27 & $\begin{array}{l}14.05 \\
1.53\end{array}$ \\
\hline $\mathrm{R}-\mathrm{S}$ & 0.01 & 0.01 & 0.94 & 138.88 & $\mathrm{C} 26$ & 0.002 & 114.17 & 0.02 & 3.49 & 084 & 0.00 & 0.66 & 0.01 & 9.09 \\
\hline$\frac{I}{\mathrm{C} 30}$ & $\frac{0.02}{0.01}$ & $\frac{0}{76.30}$ & $\begin{array}{l}0.06 \\
0.04\end{array}$ & $\frac{79.68}{1.59}$ & $\frac{\mathrm{I}}{\mathrm{R}-\mathrm{S}}$ & $\begin{array}{ll}0.04 \\
0.01\end{array}$ & $\begin{array}{l}0 \\
0\end{array}$ & 0.001 & 68.39 & \begin{tabular}{|l|l}
$\mathrm{H} 52$ \\
$\mathrm{~A} 303$
\end{tabular} & 0.00 & 6.44 & $\begin{array}{l}0.00 \\
0.4\end{array}$ & $\begin{array}{l}2.72 \\
8.31\end{array}$ \\
\hline $\mathrm{J} 61$ & 0.011 & 0.70 & 0.014 & 58.51 & $\begin{array}{l}\text { K-s } \\
\text { K64 }\end{array}$ & 0.01 & 0 & & 30.00 & A28 & 0.03 & $\frac{0.31}{5.94}$ & 0.04 & $\begin{array}{l}.311 \\
1.61\end{array}$ \\
\hline 084 & 0.01 & 0.02 & 0.04 & 48.30 & C30 & 0.01 & 26.76 & 0.04 & 0.39 & $\mathrm{~N}$ & 0.00 & 4.98 & 0.00 & 2.20 \\
\hline D35 & 0.02 & $\begin{array}{l}.97 \\
1.35\end{array}$ & 0.72 & $\begin{array}{l}45.23 \\
2.57\end{array}$ & $\begin{array}{l}\text { J61 } \\
\end{array}$ & 0.01 & 2.38 & 0.00 & 22.06 & $Q$ & 0.00 & 0 & 0.01 & 6.01 \\
\hline $\begin{array}{l}\text { K64 } \\
H 52\end{array}$ & 0.00 & 1.35 & 0.08 & 21.57 & D35 & 0.011 & $\begin{array}{l}0.00 \\
0.98\end{array}$ & 0.15 & 23.67 & K64 & 0. & $\begin{array}{l}0.73 \\
.63\end{array}$ & 0.01 & $\begin{array}{l}4.81 \\
\end{array}$ \\
\hline$\frac{\mathrm{H} 52}{0}$ & $\frac{0.01}{0.01}$ & 0.56 & $\frac{0.02}{0.02}$ & $\frac{16.71}{1427}$ & $\begin{array}{r}\text { H52 } \\
\end{array}$ & $\frac{0.01}{0}$ & $\frac{1.98}{6671}$ & 000 & $\frac{11.54}{236}$ & $\begin{array}{l}\mathrm{J} 61 \\
\mathrm{C} 30\end{array}$ & 0.00 & $\begin{array}{l}4.63 \\
307\end{array}$ & $\frac{0.00}{0}$ & 0.89 \\
\hline$\frac{Q}{\text { C19 }}$ & $\frac{0.01}{0}$ & $\frac{0}{5.70}$ & $\frac{0.02}{0.72}$ & $\frac{14.27}{7.55}$ & $\begin{array}{l}\text { A03 } \\
\text { P85 }\end{array}$ & 0 & $\frac{6.17}{0}$ & $\frac{0.00}{0.00}$ & $\frac{2.36}{7.16}$ & $\begin{array}{l}\text { C3030 } \\
\text { P85 }\end{array}$ & $\frac{0.00}{0.00}$ & $\frac{3.07}{0}$ & $\frac{0}{0.01}$ & $\frac{0.00}{1167}$ \\
\hline P85 & 0.00 & 0 & 0.03 & 12.91 & $\begin{array}{l}1050 \\
\end{array}$ & 0 & 3.52 & 0.00 & 0.38 & H51 & 0.0 & $\begin{array}{l}1.29 \\
\end{array}$ & 0.01 & 0.15 \\
\hline H50 & 0.00 & 5.96 & 0.00 & 6.84 & $Q$ & 0 & 0 & 0.000 & 2.48 & D35 & 0.0 & 0.00 & 0.00 & \\
\hline $\mathrm{N}$ & 0.01 & 1.61 & 0.00 & 1.22 & H51 & 0 & 1.56 & 0.00 & 0.64 & $\mathrm{R} \cdot \mathrm{S}$ & 0.0 & 0.00 & 0.00 & 0.94 \\
\hline $\mathrm{A}_{0.3}$ & 0 & 0.86 & 0.01 & 1.66 & J62-J63 & 0 & 0.00 & 0.00 & 2.04 & C19 & 0.00 & 0 & 0.01 & 0.52 \\
\hline H51 & 0 & 1.14 & 0.04 & 1.30 & $\mathrm{~N}$ & 0 & 0 & 0 & 2.05 & 118 & 0.00 & 0 & 0 & 0.24 \\
\hline$\frac{\mathrm{J} 62-\mathrm{J} / 63}{\mathrm{AJ2}}$ & $\frac{0}{0}$ & $\begin{array}{l}0 \\
0\end{array}$ & $\begin{array}{l}0.00 \\
0.13\end{array}$ & $\frac{2.11}{1.22}$ & $\begin{array}{l}\mathrm{A} 02 \\
084\end{array}$ & 0 & $\frac{0.22}{0}$ & 0 & $\frac{1.81}{0}$ & \begin{tabular}{|c}
$\mathrm{A} 202$ \\
$\mathrm{~J} 62 \cdot \mathrm{J} 63$
\end{tabular} & $\frac{0}{0}$ & $\frac{0.02}{0.00}$ & $\begin{array}{l}0 \\
0\end{array}$ & $\frac{0.14}{0.10}$ \\
\hline
\end{tabular}

* Sectors are ranked according to their foreign employment effects. 
Annex: 2

\begin{tabular}{|c|c|c|c|c|c|c|c|c|c|c|c|c|c|c|}
\hline \multirow{3}{*}{\begin{tabular}{|c|} 
Sectors \\
ISIC \\
Rev. 4* \\
\end{tabular}} & \multirow{3}{*}{$\begin{array}{c}\begin{array}{c}\text { Domestic } \\
\text { Employment } \\
\text { (persons) }\end{array} \\
\text { The employment } \\
\text { effect of export } \\
\text { content of } \\
\text { imports }\end{array}$} & \multirow{2}{*}{\multicolumn{3}{|c|}{$\begin{array}{c}\text { Germany } \\
\begin{array}{c}\text { Foreign Employment } \\
\text { (persons) }\end{array}\end{array}$}} & \multirow{3}{*}{$\begin{array}{c}\text { Sectors } \\
\text { ISIC } \\
\text { Rev. 4* }\end{array}$} & \multirow{3}{*}{\begin{tabular}{|c|}
$\begin{array}{c}\text { Domestic } \\
\text { Employment } \\
\text { (persons) }\end{array}$ \\
$\begin{array}{c}\text { The employment } \\
\text { effect of export } \\
\text { content of } \\
\text { imports }\end{array}$ \\
\end{tabular}} & \multirow{2}{*}{\multicolumn{3}{|c|}{$\begin{array}{c}\text { United States } \\
\begin{array}{c}\text { Foreign Employment } \\
\text { (persons) }\end{array}\end{array}$}} & \multirow{3}{*}{$\begin{array}{c}\text { Sectors } \\
\text { ISIC } \\
\text { Rev. 4* }\end{array}$} & \multirow{3}{*}{$\begin{array}{c}\begin{array}{c}\text { Domestic } \\
\text { Employment } \\
\text { (persons) }\end{array} \\
\text { The employment } \\
\text { effect of export } \\
\text { content of } \\
\text { imports }\end{array}$} & \multirow{2}{*}{\multicolumn{3}{|c|}{$\begin{array}{c}\text { Italy } \\
\text { Foreign Employment } \\
\text { (persons) }\end{array}$}} \\
\hline & & & & & & & & & & & & & & \\
\hline & & $\begin{array}{c}\text { The } \\
\text { employment } \\
\text { effect of } \\
\text { imports } \\
\end{array}$ & $\begin{array}{c}\text { The employment } \\
\text { effect } \\
\text { of import content } \\
\text { of exports }\end{array}$ & \begin{tabular}{|c|} 
The employment \\
effect \\
of import from third \\
countries
\end{tabular} & & & $\begin{array}{c}\text { The } \\
\text { employment } \\
\text { efrect of } \\
\text { imports }\end{array}$ & $\begin{array}{c}\text { The employment } \\
\text { effect } \\
\text { of import content } \\
\text { of exports }\end{array}$ & \begin{tabular}{|c}
$\begin{array}{c}\text { The employment } \\
\text { effect } \\
\text { of import from third } \\
\text { countries }\end{array}$ \\
\end{tabular} & & & $\begin{array}{c}\text { The } \\
\text { employment } \\
\text { effect of } \\
\text { imports }\end{array}$ & $\begin{array}{c}\text { The employment } \\
\text { effect } \\
\text { of import content } \\
\text { of exports }\end{array}$ & $\begin{array}{c}\text { The employment } \\
\text { effect } \\
\text { of imort from third } \\
\text { countries }\end{array}$ \\
\hline $\begin{array}{l}\text { C13- } \\
\text { C15 }\end{array}$ & 94.71 & $1,303.38$ & 8.31 & 2.24 & A01 & 7.12 & $1,022.50$ & 1.49 & 48.58 & $\begin{array}{l}\text { C13- } \\
\text { C15 }\end{array}$ & 119.93 & $3,367.38$ & 36.53 & 28.22 \\
\hline C29 & \begin{tabular}{|l|}
53.53 \\
5.125
\end{tabular} & $\begin{array}{l}2,228.91 \\
14573\end{array}$ & \begin{tabular}{|l|l|}
143.87 \\
3.66
\end{tabular} & 6.45 & C24 & $\begin{array}{l}2.14 \\
.098\end{array}$ & \begin{tabular}{|l|l|}
88.55 \\
11218
\end{tabular} & 2.32 & 3.51 & C24 & 27.07 & $\begin{array}{l}635.99 \\
77081\end{array}$ & 8.80 & $\frac{10.45}{3.75}$ \\
\hline C24 & 51.35 & $\begin{array}{l}1,457.03 \\
\end{array}$ & 32.66 & 111.18 & $\begin{array}{l}\mathrm{C}^{2} 30 \\
\mathbf{C} 10\end{array}$ & 0.88 & 112.18 & 8.45 & 0.05 & C29 & 13.11 & 709.81 & 6.39 & 3.75 \\
\hline C28 & 43.35 & $1,431.51$ & 111.48 & 25.28 & $\begin{array}{l}\text { C15- } \\
\text { C. }\end{array}$ & 0.84 & 69.98 & 0.17 & 4.03 & C20 & 7.16 & 584.70 & 5.21 & 8.09 \\
\hline $\mathrm{C}^{\mathrm{C} 20}$ & \begin{tabular}{|l|l|}
6.17 \\
597
\end{tabular} & $\begin{array}{l}1.592 .32 \\
205.78\end{array}$ & 14.03 & $\begin{array}{l}9.54 \\
480\end{array}$ & $\begin{array}{l}\mathrm{C} 28 \\
\mathrm{C} 20\end{array}$ & 0.46 & $\begin{array}{l}159.06 \\
24369\end{array}$ & 1.40 & 2.26 & $\mathrm{C}^{28}$ & $\frac{6.56}{5.1}$ & 613.39 & 7.49 & $\begin{array}{l}13.75 \\
7795\end{array}$ \\
\hline $\begin{array}{l}\mathbf{A} 01 \\
\mathbf{H} 49\end{array}$ & $\frac{5.97}{5.18}$ & $\begin{array}{l}295.78 \\
29.9\end{array}$ & 0.291 & $\begin{array}{l}18.10 \\
127.24 \\
\end{array}$ & $\begin{array}{l}200 \\
\mathrm{C} 29\end{array}$ & $\begin{array}{r}0.38 \\
0.26 \\
\end{array}$ & $\begin{array}{r}243.69 \\
63.85 \\
\end{array}$ & $\frac{1.60}{0.71}$ & $\begin{array}{r}2.67 \\
0.66 \\
\end{array}$ & $\begin{array}{l}\text { A01 } \\
\text { H49 } \\
\end{array}$ & $\frac{5.11}{3.40}$ & $\frac{\frac{186.24}{55.61}}{5}$ & $\frac{0.24}{0.69}$ & $\begin{array}{l}79.75 \\
152.62\end{array}$ \\
\hline C22 & 4.78 & 397.10 & 5.35 & 20.90 & $\begin{array}{l}\text { C10- } \\
\text { C12 }\end{array}$ & 0.24 & 384.96 & 0.75 & 130.50 & C22 & 2.46 & 133.53 & 1.33 & 15.06 \\
\hline G47 & 2.94 & 4.93 & 0.63 & 50.93 & H49 & 0.20 & 19.45 & 0.16 & 47.67 & G47 & 1.21 & 26.26 & 0.28 & 20.98 \\
\hline $\begin{array}{r}446 \\
C 27\end{array}$ & 2.84 & $\begin{array}{r}42.02 \\
6631\end{array}$ & $\begin{array}{l}1.46 \\
1105\end{array}$ & \begin{tabular}{|l|l|}
40.71 \\
8.33
\end{tabular} & $\begin{array}{l}\mathrm{C} 23 \\
\mathrm{C}^{2}\end{array}$ & 0.12 & $\begin{array}{l}16.11 \\
1538\end{array}$ & 0.07 & 1.60 & $\begin{array}{l}G 46 \\
\end{array}$ & 1.17 & 25.12 & 1.79 & $\begin{array}{l}44.12 \\
3.60\end{array}$ \\
\hline $\begin{array}{l}\mathrm{C} 27 \\
\mathrm{C} 25\end{array}$ & $\frac{2.74}{2.32}$ & $\frac{666.31}{244.57}$ & $\frac{11.05}{9.08}$ & $\begin{array}{r}8.33 \\
42.01 \\
\end{array}$ & $\begin{array}{l}-222 \\
G 47\end{array}$ & 0.088 & $\begin{array}{l}15.38 \\
0.34 \\
\end{array}$ & 0.12 & $\frac{6.02}{2.25}$ & $\begin{array}{l}\mathrm{C} 27 \\
\mathrm{C} 25\end{array}$ & $\begin{array}{l}1.03 \\
0.91\end{array}$ & $\begin{array}{l}224.53 \\
132.32\end{array}$ & $\frac{1.26}{4.20}$ & $\begin{array}{l}3.60 \\
44.98\end{array}$ \\
\hline C17 & 1.30 & 516.63 & 1.87 & & 646 & 0.07 & 0.06 & 0.14 & 9.55 & $\mathrm{C} 23$ & 0 & 135.07 & 0.32 & $\begin{array}{l}4.96 \\
8.79\end{array}$ \\
\hline $\mathrm{C} 23$ & 1.21 & 185.05 & 0.54 & 4.60 & $\mathrm{C} 25$ & 0.06 & 28.82 & 1.22 & 6.98 & B & 0.59 & 1.22 & 0.00 & 1.75 \\
\hline $\mathrm{C} 26$ & 0.90 & $1,224.80$ & 2.75 & 1.83 & C17 & 0.05 & 242.74 & 0.23 & 0.70 & $\begin{array}{l}{ }^{10-} \\
\mathrm{C} 12\end{array}$ & 0.36 & 307.44 & 0.28 & 223.26 \\
\hline $\begin{array}{l}\text { C31- } \\
\text { C32 }\end{array}$ & 0.70 & 98.54 & 0.83 & 2.85 & B & 0.03 & 5.93 & 0.24 & 15.45 & C30 & 0.30 & 24.13 & 0.34 & 0.15 \\
\hline $\begin{array}{l}\mathrm{Cl1}- \\
\mathrm{C12}\end{array}$ & 0.66 & 474.90 & 0.98 & 38.15 & I & 0.03 & 0.00 & 0.07 & 14.34 & $F$ & 0.28 & 5.15 & 0.61 & 66.27 \\
\hline $\begin{array}{c}\mathbf{F} \\
\mathbf{D} 35\end{array}$ & $\begin{array}{l}0.58 \\
045\end{array}$ & $\frac{39.83}{21.57}$ & 2.94 & $\frac{113.34}{5.50}$ & $\frac{\mathrm{D} 35}{\mathrm{~F}}$ & $\frac{0.02}{0.02}$ & $\begin{array}{l}0.46 \\
0.00\end{array}$ & 0.00 & 0.96 & $\begin{array}{l}\text { C17 } \\
\text { D35 }\end{array}$ & 0.23 & \begin{tabular}{|l|l|}
150.07 \\
3.46
\end{tabular} & 0.14 & 2.39 \\
\hline$\frac{\mathrm{N} 30}{\mathrm{~N}}$ & $\frac{0.05}{0.40}$ & $\frac{22.57}{0.77}$ & $\frac{0.22}{0.98}$ & $\begin{array}{l}5.50 \\
61.87\end{array}$ & $\begin{array}{l}\mathrm{F} \\
\mathrm{H} 50 \\
\end{array}$ & $\frac{0.02}{0.01}$ & $\frac{0.00}{1.32}$ & 0.000 & $\frac{12.91}{0.07}$ & 1 & 0.21 & $\begin{array}{l}3.46 \\
0.39 \\
\end{array}$ & 0.004 & $\begin{array}{l}3.13 \\
9.63 \\
\end{array}$ \\
\hline C18 & 0.29 & 64.66 & 0.28 & 4.46 & H51 & 0.01 & 1.19 & 0.00 & 0.80 & $\begin{array}{l}\text { C31- } \\
\text { C12 }\end{array}$ & 0.19 & 60.66 & 0.20 & 6.79 \\
\hline B & 0.29 & 0.62 & 0.01 & 1.03 & C26 & 0.01 & 215.83 & 0.19 & 0.53 & $\mathrm{~N}$ & 0.14 & 6.52 & 0.76 & $\begin{array}{l}19.57 \\
\end{array}$ \\
\hline H50 & 0.24 & 21.94 & 0.05 & 0.04 & 084 & 0.01 & 1.47 & 0.70 & 36.95 & H52 & 0.14 & 27.26 & 0.28 & 7.25 \\
\hline$\frac{I}{C 30}$ & 0.23 & \begin{tabular}{|l|l}
0.77 \\
16.90
\end{tabular} & 0.05 & $\begin{array}{l}4.07 \\
0.17\end{array}$ & $\frac{\mathrm{C} 27}{\mathrm{~N}}$ & $\frac{0.00}{0.00}$ & $\frac{31.14}{8.34}$ & 0.06 & 0.81 & $\begin{array}{l}\mathrm{C} 26 \\
\mathrm{C} 16\end{array}$ & 0.12 & $\frac{172.58}{77.38}$ & 0.12 & $\frac{1.39}{1.15}$ \\
\hline $\mathrm{C} 16$ & 0.15 & 131.90 & 0.16 & 1.22 & $\begin{array}{l}\mathrm{C}_{3} 31- \\
\mathrm{Cu}^{2}\end{array}$ & 0.00 & 11.02 & 0.07 & 1.12 & C19 & 0.07 & 37.87 & 0.17 & 0.92 \\
\hline H52 & 0.15 & 17.19 & 0.37 & 13.84 & C18 & 0.00 & 2.15 & 0.00 & 0.98 & H50 & 0.05 & 11.89 & 0.01 & 0.35 \\
\hline 084 & 0.10 & 0.253 & 0.23 & 28.27 & K64 & 0.00 & 7.26 & 0.00 & 0.97 & K64 & 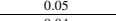 & 0.36 & 0.02 & 3.27 \\
\hline $\begin{array}{l}1061 \\
\end{array}$ & $\frac{0.07}{0.04}$ & $\begin{array}{l}0.73 \\
0.00\end{array}$ & $\frac{0.00}{0.02}$ & $\frac{1.66}{0.99}$ & $\begin{array}{l}\mathrm{C} 16 \\
\mathrm{H} 2\end{array}$ & $\frac{0.00}{0.00}$ & $\frac{65.40}{3.24}$ & 0.011 & $\frac{0.68}{1.51}$ & 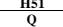 & $\begin{array}{l}0.04 \\
0.03\end{array}$ & $\begin{array}{l}.155 \\
0.60\end{array}$ & $\frac{0.00}{0.00}$ & $\begin{array}{l}0.35 \\
0.57\end{array}$ \\
\hline R-S & 0.04 & 0.00 & 0.08 & 3.68 & $Q$ & 0.00 & 0.03 & 0.01 & 0.31 & 084 & 0.03 & 0.07 & 0.00 & 4.69 \\
\hline \begin{tabular}{|l} 
K64 \\
P55
\end{tabular} & 0.04 & $\begin{array}{l}37.62 \\
000\end{array}$ & 0.03 & 2.06 & $\begin{array}{r}\text { C19 } \\
\end{array}$ & 0.00 & $\frac{12.33}{1.32}$ & 0.02 & $\begin{array}{l}0.42 \\
0.23\end{array}$ & $\begin{array}{l}\mathrm{J} 61 \\
\end{array}$ & 0.03 & $\begin{array}{l}11.19 \\
1.77\end{array}$ & 0.01 & 0.96 \\
\hline C19 & 0.02 & $\frac{0.00}{2.52}$ & $\begin{array}{l}0.01 \\
0.01\end{array}$ & $\frac{1.14}{0.30}$ & $\begin{array}{l}\mathrm{J}-\mathrm{S} \\
\mathrm{R}\end{array}$ & $\frac{0.00}{0.00}$ & $\begin{array}{l}0.21 \\
0.06\end{array}$ & $\frac{0.00}{0.04}$ & $\begin{array}{l}0.23 \\
0.86\end{array}$ & $\begin{array}{l}\text { Cl18 } \\
\text { R-S }\end{array}$ & $\frac{0.02}{0.02}$ & $\begin{array}{l}17.7 \\
0.29\end{array}$ & $\frac{0.02}{0.09}$ & $\frac{9.26}{2.27}$ \\
\hline H51 & 0.00 & 2.26 & 0.00 & 0.15 & P85 & 0. & 0.18 & 0.00 & 0.41 & P85 & 0.01 & 0.10 & 0.00 & 1.19 \\
\hline \begin{tabular}{|l|}
$\mathbf{A} 02$ \\
10203 \\
\end{tabular} & 0.00 & 0.02 & 0.00 & 0.00 & $\mathrm{~A} 022$ & 0.00 & 0.20 & 0.00 & 0.03 & $\mathrm{~A} 02$ & 0.00 & 0.00 & 0.00 & 0.00 \\
\hline$\frac{162 \cdot-763}{A 03}$ & $\frac{0.00}{0.00}$ & $\begin{array}{l}0.02 \\
0.00\end{array}$ & $\frac{0.04}{0}$ & $\frac{1.11}{0.00}$ & $\begin{array}{c}\mathrm{A} 03 \\
\mathrm{~J} 62 \mathrm{~J} 63\end{array}$ & $\frac{0.00}{0}$ & $\frac{0.02}{0.04}$ & $\frac{0.00}{0.02}$ & $\frac{0.10}{0.15}$ & $\begin{array}{c}\mathrm{A} / \mathrm{3} \\
\mathrm{J} 62 \mathrm{~J} 63\end{array}$ & 0.000 & 0.055 & $\frac{0.00}{0.0}$ & 0.017 \\
\hline & & & & & & & & & & & & & & \\
\hline
\end{tabular}

* Sectors are ranked according to their domestic employment effects. 